\title{
Method for serial passage of infectious hematopoietic necrosis virus (IHNV) in rainbow trout
}

\author{
Juliette Doumayrou, M. Gray Ryan, Andrew R. Wargo*
}

Virginia Institute of Marine Science, William \& Mary, PO Box 1346, Gloucester Point, VA 23062, USA

\begin{abstract}
Transmission is a fundamental component of pathogen fitness. A better understanding of pathogen transmission can greatly improve disease management. In particular, controlled studies of multiple rounds of natural transmission (i.e. serial passage) can provide powerful epidemiological and evolutionary inferences. However, such studies are possible in only a few systems because of the challenges in successfully initiating and maintaining transmission in the laboratory. Here we developed an efficient and reproducible cohabitation method for conducting controlled experiments investigating the effects of serial passage on infectious hematopoietic necrosis virus (IHNV) in rainbow trout. This method was used to investigate the transmission efficiency and kinetics of viral shedding of IHNV over 3 serial passages. Transmission efficiency decreased from 100 to $62.5 \%$ over the passage steps and was associated with a decrease in virus shedding into water. A shift in the peak of viral shedding was also observed, from Day 2 post immersion for passage 0 to at least $24 \mathrm{~h}$ later for all subsequent passages. Finally, the characterization of viruses after 1 round of transmission and propagation on cells showed no change in glycoprotein (G gene) sequences or viral virulence compared to the ancestral virus stock. The methods developed provide valuable tools for reproducible population-level studies of IHNV epidemiology and evolution.
\end{abstract}

KEY WORDS: Transmission $\cdot$ Evolution $\cdot$ Viral shedding $\cdot$ Virulence $\cdot$ Salmonid

\section{INTRODUCTION}

Understanding pathogen transmission dynamics can provide powerful insights into infectious disease management. Ultimately, transmission dynamics determine the rate at which pathogens spread and how many hosts become infected (Anderson \& May 1992, Nelson \& Williams 2013). Despite their epidemiological importance, pathogen transmission dynamics are difficult to study, are rarely quantified, and frequently warrant further investigation. When transmission has been studied, it is typically inferred either from disease dynamics at a host population level, from in vitro studies, or under artificial transmission routes (Wargo \& Kurath 2012). Although these studies can be highly informative, they are often limited in their ability to

${ }^{*}$ Corresponding author: arwargo@vims.edu accurately predict transmission on an individual host basis or how these dynamics change as the pathogen undergoes multiple rounds of transmission from one host to the next. The ability to make such predictions can be greatly facilitated by controlled in vivo laboratory studies using multiple rounds of natural host-tohost transmission (e.g. Ebert 1998, Mackinnon \& Read 2004, Yourth \& Schmid-Hempel 2006, Chapuis et al. 2011). These serial passage experiments (SPEs) can yield critical epidemiological information (Ebert 1998). Such a method for transmission and epidemiological inference would be particularly beneficial for management of the prevalent fish pathogen infectious hematopoietic necrosis virus (IHNV), which despite various control efforts remains highly problematic in the culture of salmonids.

(C) The authors 2019. Open Access under Creative Commons by Attribution Licence. Use, distribution and reproduction are unrestricted. Authors and original publication must be credited. 
IHNV is a single-stranded negative-sense $11.1 \mathrm{~kb}$ RNA virus (species Salmonid novirhabdovirus) in the genus Novirhabdovirus and family Rhabdoviridae (Schütze et al. 1995). The virus typically causes an acute virulent disease in many species of salmon and trout and is of global concern for aquaculture, fisheries, and conservation (Kim et al. 2005, Bootland \& Leong 2011, OIE 2017). Juvenile salmonids are the most susceptible to disease caused by the virus, but infection and symptoms can also occur in adult fish (Bootland \& Leong 2011). IHNV was first identified in the Pacific Northwest region of North America, where it is believed to have originated, but it has since spread and become one of the most prominent salmonid pathogens around the world, particularly in rainbow trout Oncorhynchus mykiss aquaculture (Nichol et al. 1995, Kurath et al. 2003). Because of its management importance, the virus has been extensively studied (reviewed by Dixon et al. 2016), with a growing body of literature on viral fitness and emergence, which is believed to be driven by transmission (Wargo et al. 2012, 2017, Wargo \& Kurath 2012, Kell et al. 2013, 2014, Breyta et al. 2014, 2016, McKenney et al. 2016). However, few studies have directly quantified the transmission dynamics of IHNV, particularly through multiple rounds of transmission (Foreman et al. 2015, Dixon et al. 2016).

IHNV is transmitted via fish bodily fluids such as urine, feces, milt, mucus, or decay and ingestion of carcasses (Mulcahy et al. 1983, Nishimura et al. 1988, LaPatra et al. 1989, Bootland \& Leong 2011). This can result in direct horizontal transmission through contaminated water, feed, or aquaculture supplies (Amend 1975). Eggs can also become externally contaminated resulting in fish becoming infected upon hatching, often referred to as pseudo-vertical transmission, which is prevented in aquaculture with iodine treatment (Mulcahy et al. 1983). Because juvenile fish typically suffer more clinical disease, they were originally believed to be the primary source of transmission, but recent epidemiological studies suggest adult fish may play an important role (Breyta et al. 2016, 2017, Ferguson et al. 2018). Transmission within and between aquaculture and wild fish occurs and is complex (Troyer \& Kurath 2003, Saksida 2006); thus, a better understanding of transmission dynamics at the individual fish level could help to disentangle this complexity.

Previous experimental studies of IHNV transmission typically used a cohabitation design where large groups of infected and naïve fish were held together for 11 to $35 \mathrm{~d}$. Infection status of naïve fish (transmission) was then assessed through disease symptoms or mortality and confirmed in a subset of fish using traditional virological methods such as plaque assays (Amend 1975, Mulcahy et al. 1983, Traxler et al. 1993, Ogut \& Reno 2004a). These studies provided valuable insights into the process of disease dynamics at a population scale, revealing that these dynamics are acute and influenced by environmental parameters such as fish density (e.g. Ogut \& Reno 2004a). However, these studies were limited in their ability to track transmission on an individual fish basis, determine how many rounds of transmission occurred, classify the source of infection (donor fish versus recently infected naïve fish), and accurately quantify transmission in the absence of clinical disease. The number of biological replicates possible with this large cohabitation study design is also limited. Ultimately, these limitations made it difficult to estimate important epidemiological parameters (Anderson \& May 1992, van den Driessche \& Watmough 2002).

More recently, viral shedding has been used as a proxy for transmission. These studies suggest that there is a significant degree of individual host variation, in the amount of viral shedding, which is influenced by a variety of factors such as within-host viral load, host genetics, virus entry, infectious dose, environmental conditions, and exposure dose (Wargo \& Kurath 2011, Wargo et al. 2012, 2017, Garver et al. 2013, Langwig et al. 2017). However, these studies assume that transmission is proportional to the quantity of viral shedding, which has not been fully validated. These previous studies also investigated shedding from fish infected after waterborne immersion with viruses previously grown in vitro on cells, rather than directly shed from fish. It is unknown whether the infectivity and transmission dynamics differs between cultured and naturally shed virus.

In this study, we developed a quick, efficient, and reproducible procedure for studying transmission of IHNV in serial passage using a natural cohabitation method under laboratory conditions. This method was designed to allow precise quantification of the level of transmission after each round of transmission and incorporate a large number of biological replicates. These studies made it possible to elucidate the relationship between viral shedding and transmission, determine how the kinetics of shedding change after each round of transmission, and investigate how host density affects transmission of the virus. We also characterized the virus for its glycoprotein (G) gene sequence and virulence after 1 round of transmission to investigate potential effects of serial passage on viral selection and evolution. 


\section{MATERIALS AND METHODS}

\subsection{Fish-to-fish viral transmission}

Several experiments were conducted to evaluate the efficiency of fish-to-fish transmission of IHNV in rainbow trout Oncorhynchus mykiss and develop a serial passage method. A specific pathogen free aquaculture rainbow trout line, provided by Clear Springs Foods, was used in these experiments. Fish weighed approximately 1 to $7 \mathrm{~g}$ and were maintained in specific pathogen free, UV-irradiated fresh water at $15^{\circ} \mathrm{C}$. These experiments were approved by William \& Mary's Institutional Animal Care and Use Committee (IACUC) under IACUC protocol 2014-1117-12311-arwargo. The virus used in these experiments was IHNV (species Salmonid novirhabdovirus) isolate LR80 (genotype mG007M; GenBank accession no. L40878), which is from the $M$ genogroup believed to be adapted to $O$. mykiss at $15^{\circ} \mathrm{C}$ (Nichol et al. 1995, Kurath et al. 2003, Garver et al. 2006). The virus was propagated and titered on an Epithelioma papulosum cyprini (EPC) fish cell line (Fijan et al. 1983) prior to experiments, then stored as virus stocks at $-80^{\circ} \mathrm{C}$ as previously described (Batts \& Winton 1989). The virus dose was not reconfirmed at the time of exposure in these experiments but Batts \& Winton (1989) indicate titers of viral stocks are stable.

Six different transmission experiments were conducted (Fig. 1; labelled Expts 1-6). To generate passage zero $\left(\mathrm{P}_{0}\right)$, groups of rainbow trout (10-30 fish) were initially infected by immersing them in static water with supplemental aeration containing IHNV from virus stocks at a dose of $1 \times 10^{6}$ plaqueforming units (PFU) $\mathrm{ml}^{-1}$ for $1 \mathrm{~h}$ in $6 \mathrm{l}$ tanks. A $1 \mathrm{~h}$ wash (flow at $1500 \mathrm{ml} \mathrm{min}^{-1}$ ) to remove all residual virus was immediately done after the $1 \mathrm{~h}$ exposure. Then, 1 (Expts 1 and 2) or 3 (Expts 3-6) fish were transferred into individual 0.81 tanks, with aeration. In Expt 1, fish were kept in these tanks in static water for $72 \mathrm{~h}$ (Fig. 1A). At this point, $\mathrm{P}_{0}$ fish were removed and a new naive fish (referred to as $P_{1}$, i.e. passage 1 ) was added to each tank. The $\mathrm{P}_{1}$ fish were immersed for $24 \mathrm{~h}$, transferred into new tanks containing virus-free water, rinsed for $1 \mathrm{~h}$ (water flow at 250-300 $\mathrm{ml} \mathrm{min}^{-1}$ ), and held in static conditions with supplemental aeration at $15^{\circ} \mathrm{C}$ for $3 \mathrm{~d}$. We consider the initial immersion time of the naivve fish with the virus or donor fish as Day 0 in this and all other experiments. In Expts 2 to 6, each individual (Expt 2; Fig. 1B) or group (Expts 3-6; Fig. 1C) of $\mathrm{P}_{0}$ fish was left to shed the virus in static water for $24 \mathrm{~h}$. At this point, either 1 (Expt 2) or 3 (Expts 3-6) new naïve $\mathrm{P}_{1}$ fish were placed in a nylon bag and added to each tank. Fish were held in these tanks for $24 \mathrm{~h}$. This allowed for water and virus flow between the $\mathrm{P}_{0}$ and $\mathrm{P}_{1}$ fish but kept the fish separated so the viral passage could be differentiated. The $\mathrm{P}_{1}$ fish were then transferred into new tanks, released from the nylon bag, rinsed, and held in tanks for 2 (Expts 5 and 6) to 3 (Expts 2-4) days in the same conditions as for Expt 1. For Expts 5 and 6, an additional 1 (Expt 5) or 2 (Expt 6) rounds of serial passages, named passage $2\left(\mathrm{P}_{2}\right)$ and passage $3\left(\mathrm{P}_{3}\right)$, were performed, following the same procedure as for $\mathrm{P}_{0}$ fish, with cohabitation beginning $2 \mathrm{~d}$ after initial exposure (Fig. 1). The tanks were kept under continuous aeration, which also vigorously mixed the water. A volume of $800 \mu \mathrm{l}$ of water was collected daily from each individual tank at the same time each day, on the day of fish addition to the tank and subsequently for 2 to $4 \mathrm{~d}$. Water samples were stored at $-80^{\circ} \mathrm{C}$ daily and later processed to evaluate transmission success and the cumulative kinetics of viral shedding of each passage step (Expts 1-3, 5, and 6). Water samples were only collected at 1 time point (Days 2 and 4 for $\mathrm{P}_{0}$ and $\mathrm{P}_{1}$ fish, respectively) in Expt 4 . The fish were then euthanized by adding $0.27 \mathrm{mg} \mathrm{ml}^{-1}$ Tricaine-S (MS 222; Western Chemical) buffered with $0.09 \mathrm{mg} \mathrm{ml}^{-1}$ sodium bicarbonate directly into each tank. All the fish from 1 tank within a passage were collected into a single Whirl-pak ${ }^{\circledR}$ bag (Nasco) and stored at $-80^{\circ} \mathrm{C}$. None of the fish died during any of the transmission experiments.

\subsection{Viral quantification in water}

Total RNA was extracted from water samples with a Tecan Freedom EVO ${ }^{\circledR} 100$ liquid handler using the cador Pathogen 96 QIAcube HT Kit (Qiagen), according to the manufacturer's protocol. A volume of $105 \mu$ l of VXL mix (84 $\mu$ l buffer VXL with additional $20 \mu$ l Proteinase K and $1 \mu \mathrm{g}$ carrier RNA) was added to each $210 \mu \mathrm{l}$ water sample, vortexed at $1000 \mathrm{rpm}$ for $30 \mathrm{~s}$, and incubated for $5 \mathrm{~min}$ at room temperature. A volume of $367.5 \mu \mathrm{l}$ of buffer ACB was added, the sample was vortexed (1000 rpm for $30 \mathrm{~s}$ ), and then $685 \mu \mathrm{l}$ of the sample was transferred to the capture plate and subjected to a 3 min vacuum at $25 \mathrm{kPa}$. Each sample was washed using $600 \mu \mathrm{l}$ of buffers AW1 and AW2 and eluted with a 1 min vacuum at $35 \mathrm{kPa}$, then rinsed with $600 \mu \mathrm{l}$ absolute ethanol (vacuum for $30 \mathrm{~s}$ at $35 \mathrm{kPa}$ ). Subsequently, the capture plate was dried for $1 \mathrm{~min}$ at $70 \mathrm{kPa}$, then for 2 min at 


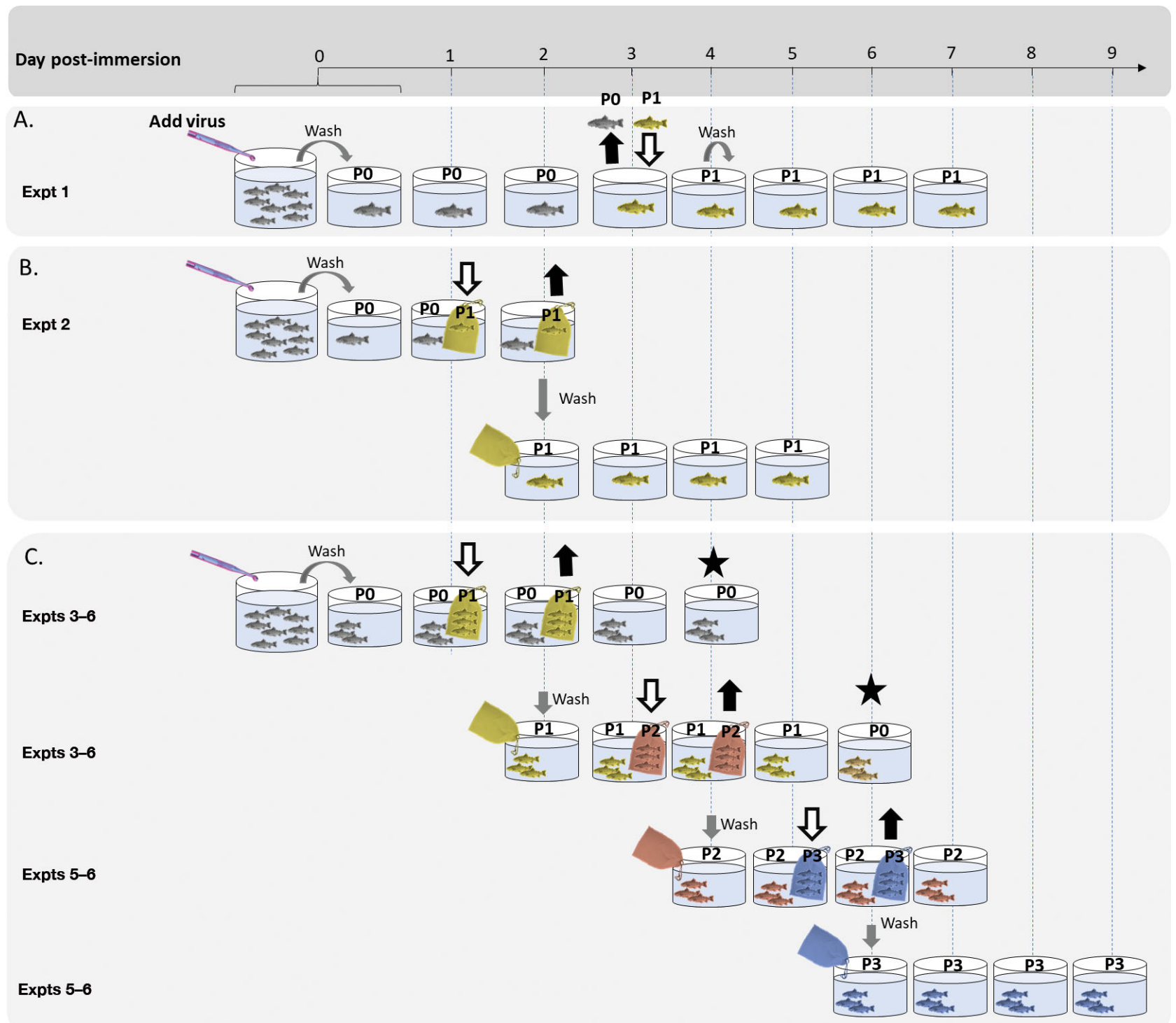

Fig. 1. In vivo serial passage designs for experiments on infectious hematopoietic necrosis virus in rainbow trout. (A) Expt 1, (B) Expt 2, and (C) Expts 3 to 6, as described in Section 2. $(\Rightarrow)$ : add fish to tank; $(\rightarrow)$ : remove fish from tank; $(\vec{b})$ : fish transfer or $1 \mathrm{~h}$ wash. Black stars indicate fish held in static conditions in tanks for $3 \mathrm{~d}$ only in Expts 3 and 4; otherwise, they were held static for $4 \mathrm{~d}$ as described in Section 2. All donor and recipient tanks were sampled in these experiments. P: passage

$35 \mathrm{kPa}$. Total RNA was eluted by incubating $100 \mu \mathrm{l}$ of buffer AVE on the column for 2 min, then applying a $70 \mathrm{kPa}$ vacuum for $6 \mathrm{~min}$. All extracted RNA was stored at $-80^{\circ} \mathrm{C}$ until further processing. RNA samples were converted to cDNA using $11 \mu$ l of extracted RNA sample and Moloney murine leukemia virus reverse transcriptase (Promega), random hexamers, and oligo dT in a total reaction volume of $20 \mu \mathrm{l}$ as described in Wargo et al. (2010). The cDNA was stored at $-80^{\circ} \mathrm{C}$ until future use.

For virus quantification, cDNA samples were diluted 1:2 with RNase/DNase-free water (Fisher Sci- entific) and then underwent quantitative PCR (qPCR), using TaqMan probe IHNV N 818 MGB, forward primer IHNV N $796 \mathrm{~F}$, and reverse primer IHNV N 875R, targeting the viral nucleocapsid (N) gene, in a $12 \mu \mathrm{l}$ reaction as previously described (Purcell et al. 2013). Viral quantification was performed in 384-well optical plates (Applied Biosystems) with the APC viral N gene plasmid standard (Purcell et al. 2013). The qPCR quantified the number of viral RNA copies, presented here as virus copies per milliliter of water. A $\log _{10}(x+1)$ transformation was applied to the viral load data for figures and analyses. 


\subsection{Virus propagation from fish}

The $\mathrm{P}_{1}$ fish from the 3 replicate tanks in Expt 4 were thawed on ice for approximately $3 \mathrm{~h}$ and weighed. This experiment was chosen at random to isolate and characterize the virus after 1 round of passage $\left(\mathrm{P}_{1}\right)$. A volume of $2 \mathrm{ml} \mathrm{g}^{-1}$ of fish of minimum essential medium (MEM) supplemented with 100 units $\mathrm{ml}^{-1}$ of penicillin (Gibco), $100 \mathrm{\mu g} \mathrm{ml}^{-1}$ streptomycin (Gibco), $20 \mu \mathrm{g} \mathrm{ml}^{-1}$ gentamycin (Gibco), $2.5 \mu \mathrm{g} \mathrm{ml}^{-1}$ Amphotericin B (Gibco), and $7 \mathrm{ml} 1 \mathrm{M}$ Tris-HCl (Sigma) (media named MEM-0) was added to each Whirl-pak ${ }^{\circledR}$ (Nasco) bag of 3 fish. Using the flat bottom of a small glass beaker, pressure was applied to the fish through the bag to homogenize their contents. Once all the fish tissue was dislodged from the skin and no large pieces remained, the contents of each bag were transferred into separate $50 \mathrm{ml}$ sterile centrifuge tubes and stored on ice. A second aliquot of $2 \mathrm{ml}$ MEM- $0 \mathrm{~g}^{-1}$ of fish was used to rinse the remaining fish tissue into the centrifuge tube. The 3 centrifuge tubes were then centrifuged at $1000 \times g$ for $10 \mathrm{~min}$ at $4{ }^{\circ} \mathrm{C}$, and the resulting supernatant was removed and stored at $-80^{\circ} \mathrm{C}$. The pellet was discarded.

Each of the 3 virus isolates (P1fish_1 to P1fish_3; Expt 3) were propagated on $2 \mathrm{~d}$ old confluent monolayers of EPC cells (Fijan et al. 1983) in $75 \mathrm{~cm}^{2}$ flasks containing $1 \times 10^{8}$ cells at confluence. The cells were maintained in MEM-0 supplemented with $10 \%$ fetal bovine serum (Gibco), 2 mM L-glutamine (Gibco), and $10 \mathrm{ml} 7.5 \%$ sodium bicarbonate substituted for the Tris- $\mathrm{HCl}$ (media named MEM-10). A $500 \mu \mathrm{l}$ volume of each fish supernatant virus isolate (P1fish_1 to P1fish_3), positive control (LR80 ancestor stock), and negative control (MEM-10) was added to their respective flask, manually rocked back and forth gently for $10 \mathrm{~s}$, and incubated at $15^{\circ} \mathrm{C}$ for 7 to $9 \mathrm{~d}$. Each day, the flasks were checked for cytopathic effect, which was quantified as percent of cell monolayer lysed. Once approximately $80 \%$ of the cell monolayer had lysed, the contents of the flask were transferred into a $50 \mathrm{ml}$ centrifuge tube and centrifuged at $1000 \times g$ for $10 \mathrm{~min}$ at $10^{\circ} \mathrm{C}$. The supernatants were then collected and stored at $-80^{\circ} \mathrm{C}$ for future use. These viral isolates were labelled P1cell_1, P1cell_2, and P1cell_3.

Viruses collected directly from fish supernatants (P1fish_1 to P1fish_3) and from propagation on fish cells (P1cell_1 to P1cell_3) were titered on EPC cells using plaque assays. Serial 10-fold dilutions of each sample were prepared in MEM-0, and $200 \mu \mathrm{l}$ of each dilution $\left(10^{-1}-10^{-4}\right.$ for viruses from fish supernatants and $10^{-4}-10^{-7}$ dilutions for viruses propagated on cells) was inoculated into the wells containing $1 \times 10^{6}$ cells pretreated with a final concentration of $7 \%$ (w/v) polyethylene glycol (PEG 20000; Sigma) in triplicate as described in Batts \& Winton (1989). A positive control (LR80 ancestor stock with a mean titer of $2.22 \times 10^{9} \mathrm{PFU} \mathrm{ml}^{-1}$ ) and a negative control (MEM-10) were additionally titered. The multiplicity of infection (MOI) was estimated for virus used to seed the P1cell_1 to P1cell_3 cultures, using the viral titer determined for the P1fish_1 to P1fish_3 isolates that initiated these cultures. The MOI was 0.022 , 0.0094, and 0.006 for P1cell_1, P1cell_2, and P1cell_3, respectively.

\subsection{Sequencing of the $\mathrm{G}$ gene}

Viral RNA was extracted from $200 \mu \mathrm{l}$ of virus isolates P1fish_1 to P1fish_3, P1cell_1 to P1cell_3, and a negative control (water) using the QIAamp cador Pathogen Mini Kit (Qiagen) according to the supplier's procedure. The extracted samples were eluted in $100 \mu \mathrm{l}$ of elution buffer and stored at $-80^{\circ} \mathrm{C}$. RNA samples were converted to cDNA as described in Section 2.2.

The full open reading frame encoding region of the G gene was amplified by PCR for each cDNA using primers For3 (5'-CAC TTT TGT GCT TTT AGA CAG-3'; Thermo Fisher Scientific) and Rev1617.C (5'-TTC TGT CTG GTG GGG AGG A-3'). The PCR reaction was performed in a $0.2 \mathrm{ml}$ nuclease-free PCR tube containing $1 \times$ buffer, $1.5 \mathrm{mM} \mathrm{MgCl}_{2}$, $800 \mu \mathrm{M}$ dNTPs (200 $\mu \mathrm{M}$ each), $400 \mathrm{nM}$ both primers, 2 units of Platinum ${ }^{\circledast}$ Taq DNA polymerase (Invitrogen; Thermo Fisher Scientific), and $2 \mu \mathrm{l}$ of cDNA diluted 1:2 in water, with a volume totaling $25 \mu \mathrm{l}$. The tubes were held for $2 \mathrm{~min}$ at $94^{\circ} \mathrm{C}$ followed by 35 cycles of $30 \mathrm{~s}$ at $94^{\circ} \mathrm{C}, 30 \mathrm{~s}$ at $55^{\circ} \mathrm{C}$, and $2 \mathrm{~min}$ at $72^{\circ} \mathrm{C}$. They were then held for $10 \mathrm{~min}$ at $72^{\circ} \mathrm{C}$ and stored at $-80^{\circ} \mathrm{C}$. Amplification of DNA during PCR was verified through gel electrophoresis before purification.

The PCR products were purified with a QIAquick PCR Purification Kit (Qiagen) according to the manufacturer's protocol. DNA was eluted in $25 \mu \mathrm{l}$ of $1 \times$ low TE buffer (pH 8.0). The DNA was quantified using a Qubit ${ }^{\circledR}$ dsDNA BR Assay Kit (Invitrogen), and the purified DNA was sequenced using BigDye Terminator technology (PE Applied Biosystems). For sequencing, $25 \mathrm{ng}$ of purified DNA was incubated in a $5 \mu \mathrm{l}$ reaction volume containing $0.875 \mu \mathrm{l}$ buffer, $0.25 \mu \mathrm{l}$ of BigDye reagent, and $640 \mathrm{nM}$ of primer at $96^{\circ} \mathrm{C}$ for $1 \mathrm{~min}$ followed by 25 cycles of $96^{\circ} \mathrm{C}$ for $10 \mathrm{~s}, 50^{\circ} \mathrm{C}$ for $5 \mathrm{~s}$, and $60^{\circ} \mathrm{C}$ for $4 \mathrm{~min}$. Six primers were used to 
obtain the full G gene sequence (3 forward primers: For3, For714 [5'-CAC CTC TTT GTT GAT AAA ATC-3'], and For1142 [5'-GAG GTA TCC AAG GAC AGG-3']; 3 reverse primers: Rev1617.C, Rev707 [5'ATC TCT TGG CTG GAA TCA-3'], and Rev972 [5'GAG GCC TTC ACC AGA TC-3']). The sequencing products were precipitated with $95 \%$ ethanol and 3 M sodium acetate $(\mathrm{pH} 5.2)$, centrifuged at $2500 \times g$ for $45 \mathrm{~min}$, and resuspended in $20 \mu \mathrm{l}$ of Hi-Di Formamide. They were then denatured for $2 \mathrm{~min}$ at $95^{\circ} \mathrm{C}$ and loaded onto the ABI 3130XL sequencer. Geneious 10.2.3 was used to analyze chromatograms, trim the sequences, and obtain the consensus sequence of the LR80 ancestor stock and the 6 virus isolates.

\subsection{Virulence challenge}

The virulence of the LR80 ancestor stock and the 3 virus isolates from $\mathrm{P}_{1}$ fish that were propagated on fish cells was assessed by challenging rainbow trout through waterborne immersion exposure (Garver et al. 2006). Viral isolates directly isolated from fish were not tested because their titers were not high enough to achieve the desired challenge dose. Fish were exposed to virus isolates in triplicate tanks ( $\mathrm{n}=$ 20 fish $\operatorname{tank}^{-1}$; mean weight $=2.74 \mathrm{~g}$ ). Fish were placed in aerated individual $6 \mathrm{l}$ tanks containing $995 \mathrm{ml}$ of pathogen-free $15^{\circ} \mathrm{C}$ water. A volume of $5 \mathrm{ml}$ of the corresponding virus isolate diluted in MEM-10, to achieve a final dose of $2 \times 10^{5} \mathrm{PFU} \mathrm{ml}^{-1}$, was then added to each tank and the water held static for $1 \mathrm{~h}$. Three additional control tanks were set up the same way but had $5 \mathrm{ml}$ of MEM-10 added in place of virus. After a $1 \mathrm{~h}$ exposure period, water flow was resumed at a rate of $100 \mathrm{ml} \mathrm{min}{ }^{-1}$ and maintained for $35 \mathrm{~d}$. Mortalities in each of the 15 tanks were recorded and removed daily for $35 \mathrm{~d}$ post challenge. At the end of the experiment, all surviving fish were euthanized as described in Section 2.1. For the duration of the experiment, fish were fed $1 \%$ body weight every other day (\#2 Crumble; Zeigler).

\subsection{Statistical analysis}

The $\log _{10}$-transformed cumulative amounts of virus shed after each serial passage in Expts 3 to 6 were analyzed using multi-factor ANOVA. Cumulative virus was measured on Day 2 for $\mathrm{P}_{0}$ and on Day 3 for all subsequent passages. The dependent variable viral load was $\log _{10}$ transformed so as to adhere to the assumptions of variance homogeneity and normality, which were validated using Levene's test and the normal probability plot of residuals. The explanatory fixed factors included experiment (Expts 3-6) and/ or passage $\left(\mathrm{P}_{0}-\mathrm{P}_{3}\right)$. Comparisons between passages steps were only made in the experiments where they occurred. This resulted in 3 separate analyses, $\mathrm{P}_{0}$ vs. $\mathrm{P}_{1}, \mathrm{P}_{1}$ vs. $\mathrm{P}_{2}$, and $\mathrm{P}_{2}$ vs. $\mathrm{P}_{3}$, in which data from some experiments were used more than once. To avoid an inflated Type I error, a Bonferroni correction was applied to account for multiple testing, where alpha was divided by 3 , such that results were considered significant if $p<0.017$. Tukey's post hoc comparisons were used to identify significant differences between factor levels. Virulence data were analyzed using survivorship analysis with a Cox proportional hazards regression from the $\operatorname{coxph}()$ function in the package survival in R (Therneau \& Grambsch 2000). The response variable was day of death, with censoring of live fish on the last day of the experiment. The explanatory factor was virus isolate. The proportional hazards assumption of the model was validated using the cox.zph function, ensuring that the parameter rho was not significantly different from zero. The inclusion of tank as a random effect was also evaluated using the Cox proportional hazards mixed-effects model with the coxme() function from the coxme package (Therneau 2015). We compared the 2 model fits using a likelihood ratio test and Akaike's information criterion (AIC) value comparison, with differences in AIC value $>2$ considered significant. Statistical analyses were carried out using $\mathrm{R}$ version 3.3.3 software (R Core Team 2013).

\section{RESULTS}

\subsection{Number of fish shedding through passages}

The efficiency of fish-to-fish transmission was investigated by quantifying the number of fish shedding at each of up to 3 passages of IHNV in rainbow trout. The unit of replication in these studies was the tank, so the numbers of fish represent the numbers of pools of 1 (Expts 1 and 2) or 3 (Expts 3-6) fish contained in each tank. All the $\mathrm{P}_{0}$ fish exposed to virus previously propagated in cell culture became infected and shed, except in Expt 1, where $90 \%$ of the $\mathrm{P}_{0}$ fish shed (Table 1 and Fig. 2A). After the first passage, only $10 \%$ of the $\mathrm{P}_{1}$ fish shed detectable virus in Expt 1 without cohabitation (Table 1). In Expt 2, where a single $\mathrm{P}_{0}$ fish was placed in cohabitation with a single $\mathrm{P}_{1}$ fish, no transmission occurred (Table 1). Because of the lack of transmission be- 
Table 1. Transmission efficiency across 6 experiments. Virus quantity = cumulative amount of virus shed by $\mathrm{P}_{0}$ fish at Day 2 in $\log _{10}$ (virus RNA copies $\left.\mathrm{ml}^{-1} \mathrm{H}_{2} \mathrm{O}+1\right)( \pm \mathrm{SE})$. Transmission efficiency ratio was calculated $2 \mathrm{~d}$ after the start of exposure to virus for $\mathrm{P}_{0}$ and $3 \mathrm{~d}$ after the start of cohabitation for $\mathrm{P}_{1}$ to $\mathrm{P}_{3}$. $\mathrm{P}$ : passage

\begin{tabular}{|lccccccc|}
\hline \multirow{2}{*}{$\begin{array}{c}\text { Expt } \\
\text { replicates }\end{array}$} & $\begin{array}{c}\text { No. of fish } \\
\text { replicate }\end{array}$ & Virus & \multicolumn{5}{c|}{ Transmission efficiency (positive/total) } \\
\hline 1 & 10 & 1 & $4.24 \pm 0.51$ & $9 / 10$ & $1 / 9$ & NA & NA \\
2 & 5 & 1 & $4.95 \pm 0.23$ & $5 / 5$ & $0 / 5$ & NA & NA \\
3 & 5 & 3 & $6.32 \pm 0.17$ & $5 / 5$ & $5 / 5$ & NA & NA \\
4 & 3 & 3 & $4.43 \pm 0.15$ & $3 / 3$ & $3 / 3$ & NA & NA \\
5 & 10 & 3 & $5.13 \pm 0.07$ & $10 / 10$ & $10 / 10$ & $9 / 10$ & NA \\
6 & 10 & 3 & $4.58 \pm 0.10$ & $10 / 10$ & $10 / 10$ & $8 / 10$ & $5 / 8$ \\
\hline
\end{tabular}

ding from Day 1 to Day 2 (Fig. 2). The cumulative amount of virus then tended to decrease after Day 2 , although the change was not statistically significant, with a slightly larger decrease for Expt 1 $\left(\right.$ mean $\pm \mathrm{SE}_{\text {; }}$ Day 2: $4.25 \pm 1.00$, Day 4: $3.23 \pm 1.45$; Fig. 2 A) compared to Expt 2 (Day 2: $4.95 \pm 0.45$, Day 3: $4.88 \pm 0.52$; Fig. 2B). Because mean shedding peaked at Day 2 (Fig. 2), the shedding of $\mathrm{P}_{0}$ was only quantified at Day 2 in the other experiments (Expts 3-6).

tween single fish, we evaluated the efficacy of transmission using groups of 3 fish at each passage step for all subsequent experiments. In Expts 3 to 6, where groups of fish were held in cohabitation with groups of $3 \mathrm{P}_{0}$ fish, all of the $\mathrm{P}_{1}$ fish became infected and shed virus (Table 1), indicating $100 \%$ transmission. Further serial passages investigated in Expts 5 and 6, using groups of 3 donor and 3 recipient fish, indicated that transmission success steadily decreased with number of passages. Only 90 or $80 \%$ of fish (Expts 5 and 6, respectively; Table 1) became infected and shed virus after the second passage after the end of cohabitation and $62.5 \%$ after the third passage (Expt 6; Table 1).

\subsection{Kinetics of viral shedding through passages}

The kinetics of cumulative viral shedding at each of up to 3 passage steps were examined. At passage 0 , the fish in Expts 1 and 2 showed a similar pattern of no detectable shedding at Days 0 and 1, followed by a 4 to 5 order of magnitude increase in cumulative shed-
In contrast, the majority of $\mathrm{P}_{1}$ fish began shedding $48 \mathrm{~h}$ after the first exposure to virus, with only 4 of the 25 fish not shedding until $72 \mathrm{~h}$ after first exposure (Expts 3, 5, and 6; Fig. 3). Shedding from the $\mathrm{P}_{1}$ fish continued to increase until Day 3 in all experiments where it was quantified. After Day 3, cumulative shedding began to decrease in Expt 3 and was not quantified in the other experiments (Fig. 3A).

The pattern in shedding kinetics for $\mathrm{P}_{2}$ fish was more variable than the $\mathrm{P}_{0}$ and $\mathrm{P}_{1}$ fish (Fig. 4). Of the 20 fish in Expts 5 and 6 where the kinetics of cumulative shedding were quantified, 11 fish began shedding $48 \mathrm{~h}$ after first exposure to virus, 6 fish after $72 \mathrm{~h}$, and 2 fish after $96 \mathrm{~h}_{\text {; }}$ the remaining fish did not shed virus (Fig. 4). When averaging the virus shedding across all replicates, peak shedding occurred on Day 3 and then began to slightly decline in both experiments (Fig. 4). However, at the individual fish level, peak shedding was dispersed in the 2 independent experiments, with $47.4 \%$ of the fish reaching peak shedding on Day 3 (9 of 19), $26.3 \%$ on Day 2 (5 of 19 ), and $26.3 \%$ on Day 4 (5 of 19) (Expts 5 and 6; Fig. 4).
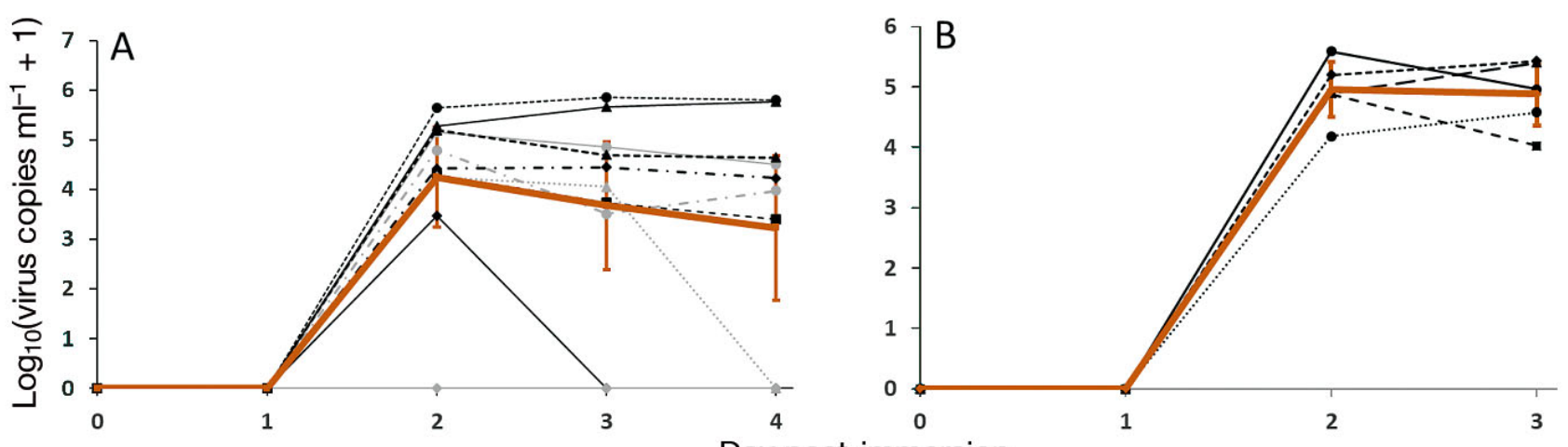

Day post-immersion

Fig. 2. Cumulative viral shedding of individual $P_{0}$ fish in static water. (A) Expt $1(n=10)$ and (B) Expt 2 (n = 5). Each line corresponds to the cumulative $\log _{10}$ (virus RNA copies $\mathrm{ml}^{-1} \mathrm{H}_{2} \mathrm{O}+1$ ) shed through time of individual fish in a tank. The bold red line represents the mean virus shed through time $\pm \mathrm{SE}$ (vertical bars). P: passage 

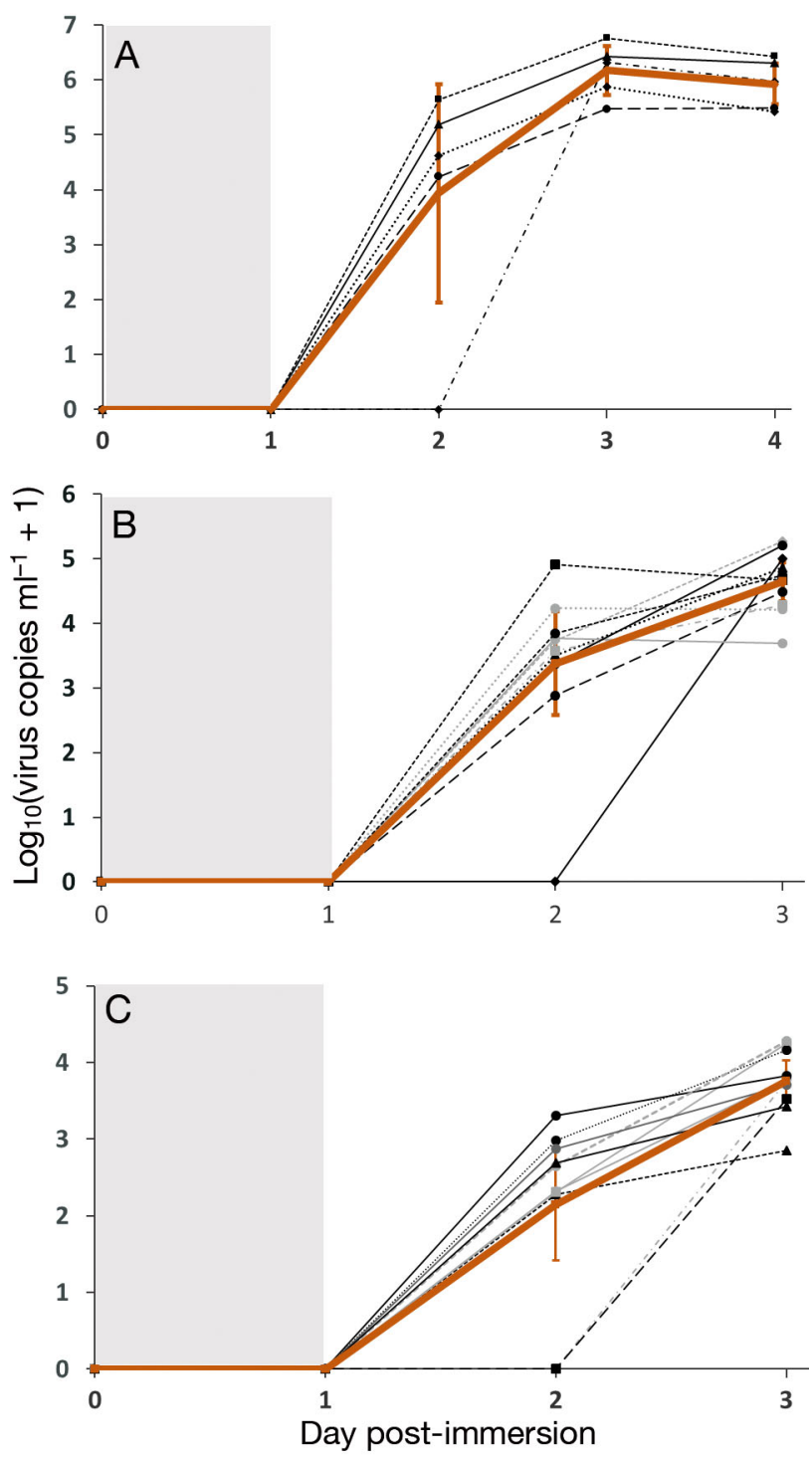

Fig. 3. Viral shedding of $P_{1}$ fish after cohabitation with $P_{0}$ fish in static water. (A) Expt $3(n=5)$, (B) Expt $5(n=10)$, and (C) Expt $6(\mathrm{n}=10)$. Each line corresponds to the cumulative $\log _{10}$ (virus RNA copies $\mathrm{ml}^{-1} \mathrm{H}_{2} \mathrm{O}+1$ ) shed through time of the 3 fish in an individual tank. The bold red line represents the mean virus shed through time $\pm \mathrm{SE}$ (vertical bars). The grey box corresponds to the time windows for the $\mathrm{P}_{0} / \mathrm{P}_{1}$ fish cohabitation. P: passage

Similar to the $\mathrm{P}_{2}$ fish, the pattern in shedding kinetics for the $\mathrm{P}_{3}$ fish was also dispersed over time. On average, the $\mathrm{P}_{3}$ fish shed the highest amount of virus into the water on Day 4 ; however, the mean shedding between Days 2, 3, and 4 was not statistically different (Expt 6; Fig. 5). At the individual level, peak shedding was also dispersed, with $50.0 \%$ of the fish reaching peak shedding on Day 4 (3 of 6), $16.7 \%$ on Day 2 ( 1 of 6 ), and $33.3 \%$ on Day 3 (2 of 6) (Expt 6; Fig. 5).

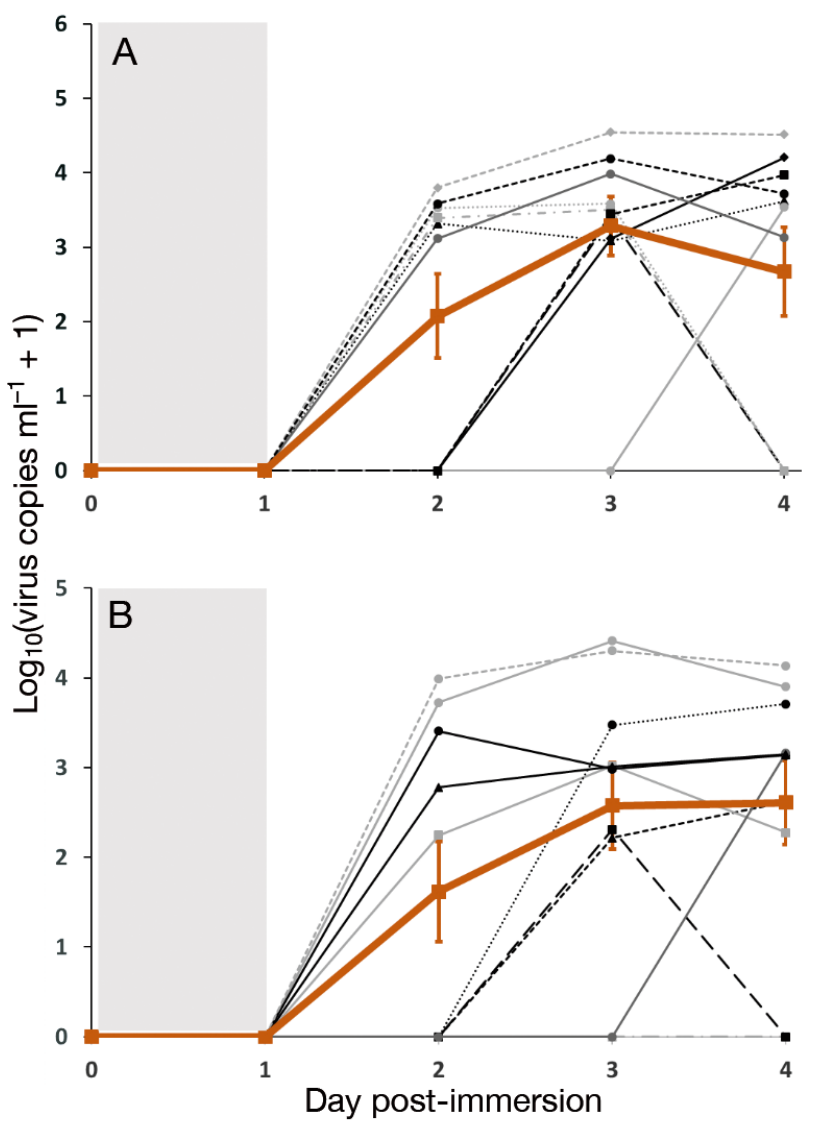

Fig. 4. Viral shedding of $\mathrm{P}_{2}$ fish after cohabitation with $\mathrm{P}_{1}$ in static water. (A) Expt $5(n=10)$ and (B) Expt $6(n=10)$. Each line corresponds to the cumulative $\log _{10}$ (virus RNA copies $\mathrm{ml}^{-1} \mathrm{H}_{2} \mathrm{O}+1$ ) shed through time of the 3 fish in an individual tank. The bold red line represents the mean virus shed through time $\pm \mathrm{SE}$ (vertical bars). The grey boxes correspond to the time windows for the $\mathrm{P}_{1} / \mathrm{P}_{2}$ fish cohabitation. $\mathrm{P}$ : passage

Finally, we compared the cumulative amount of virus shed at each of the passage steps. When comparing passages 0 and 1 , no significant interaction between experiment and passage was found (Fig. 6 ; $F_{3,48}=3.18, \mathrm{p}=0.032, \alpha=0.017$; Expts 3-6). This indicated that the overall pattern of shedding between $\mathrm{P}_{0}$ and $P_{1}$ was not significantly different for each experiment despite variable suggestive trends (Fig. 6 and Fig. A1A in the Appendix). In general, the shedding of virus in the $\mathrm{P}_{1}$ fish was significantly lower than that in the $\mathrm{P}_{0}$ fish $\left(F_{1,48}=22.55, \mathrm{p}<0.0001\right)$. A significant main effect of experiment was also observed $\left(F_{3,48}=\right.$ 68.46, p < 0.0001), such that more virus was shed overall in Expt 3 than in the other experiments (post hoc Tukey's HSD test, $\mathrm{p}<0.001$ ). When comparing passages 1 and 2, no significant interaction between experiment and passage was also found (Fig. 6; $F_{1,33}=1.50, \mathrm{p}=0.22, \alpha=0.025$; Expts 5 and 6 ). Over- 


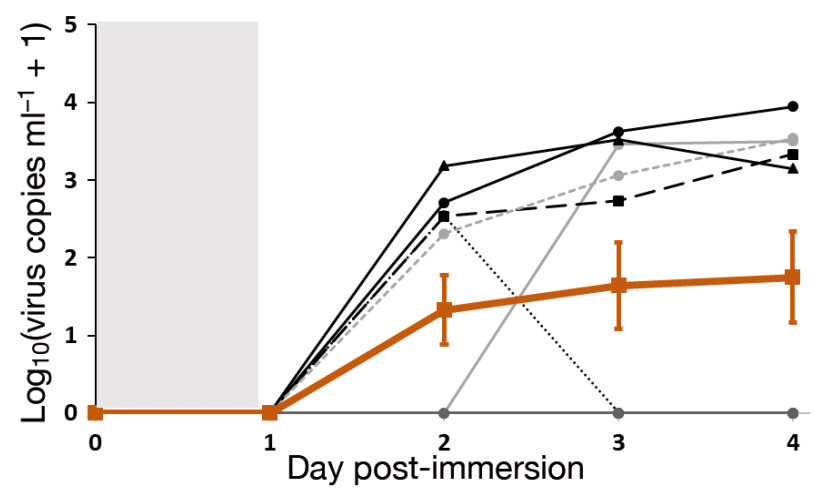

Fig. 5. Viral shedding of $\mathrm{P}_{3}$ fish after cohabitation with $\mathrm{P}_{2}$ fish in static water. Each line corresponds to the cumulative $\log _{10}$ (virus RNA copies $\mathrm{ml}^{-1} \mathrm{H}_{2} \mathrm{O}+1$ ) shed through time of the 3 fish in an individual tank (Expt 6). The bold red line represents the mean virus shed through time $\pm \mathrm{SE}$ (vertical bars). The grey boxes correspond to the time windows for the $\mathrm{P}_{2} / \mathrm{P}_{3}$ fish cohabitations. $\mathrm{P}$ : passage

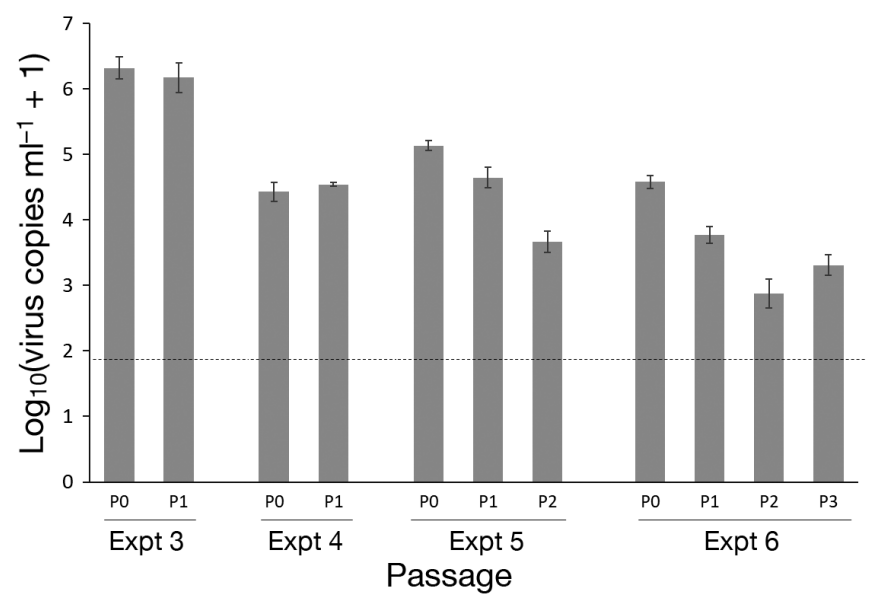

Fig. 6. Mean $( \pm \mathrm{SE})$ cumulative virus shed after $24 \mathrm{~h}$ cohabitation at each passage step $\left(\mathrm{P}_{0}\right.$ to $\left.\mathrm{P}_{3}\right)$. Shedding data of $\mathrm{P}_{0}$ fish were at Day 2 post immersion and at Day 3 for $\mathrm{P}_{1}$ to $\mathrm{P}_{3}$. Dashed line indicates the virus detection threshold determined using the $\mathrm{N}$ gene plasmid standard as described in Purcell et al. (2013). P: passage

all, the shedding of virus in the $\mathrm{P}_{2}$ fish was significantly lower than that in the $\mathrm{P}_{1}$ fish in all experiments where examined (Fig. 6 and Fig. A1B; $F_{1,33}=17.60$, $\mathrm{p}<0.001$; Expts 5 and 6). No significant differences were observed in viral shedding between $\mathrm{P}_{2}$ and $\mathrm{P}_{3}$ (Fig. $6 ; F_{1,11}=0.03, \mathrm{p}=0.88 ;$ Expt 6 ).

\subsection{Quantity of virus isolated from fish}

The virus was harvested, propagated, and quantified from the pools of 3 fish from each tank of passage 1 in Expt 4. Two of the virus isolates (P1fish_1 and P1fish_2) harvested directly from fish lysed approximately 90 to $95 \%$ of the cells by $4 \mathrm{~d}$ post infection, whereas the third virus isolate directly from fish (P1fish_3) only lysed $80 \%$ by Day 6 . The LR80 positive control isolate lysed approximately $80 \%$ of cells by $6 \mathrm{~d}$ post infection, and none of the cells were lysed in the negative control culture. The concentration of the 3 viral isolates harvested directly from fish was $4.36 \times 10^{6}$ (P1fish_1), $1.88 \times 10^{6}$ (P1fish_2), and $1.25 \times 10^{5} \mathrm{PFU} \mathrm{ml}^{-1}$ (P1fish_3). After 1 round of passage of the virus isolates from the fish supernatants through EPC cells, the virus concentrations were $2.28 \times 10^{8}$ (P1cell_1), $1.72 \times 10^{8}$ (P1cell_2), and $3.19 \times 10^{8} \mathrm{PFU} \mathrm{ml}{ }^{-1}$ (P1cell_3). Their titers were similar to the LR80 positive control $(3.04 \times$ $10^{8} \mathrm{PFU} \mathrm{ml} l^{-1}$ ).

\subsection{Genetics of virus after transmission}

The coding region of the G gene for each IHNV virus isolate directly harvested from fish and after 1 round of propagation on EPC cells was determined using Sanger sequencing. We obtained the complete $\mathrm{G}$ gene sequences of the 3 viral isolates extracted from fish (P1fish_1 to P1fish_3) and from propagation on cells (P1cell_1 to P1cell_3) as well as the original sequence of the virus stock. Comparative analysis between sequences revealed no genetic differences between the virus isolates and the virus stock.

\subsection{Virulence of virus after transmission}

The virulence of 3 IHNV isolates, which had undergone 1 round of transmission through rainbow trout $\left(\mathrm{P}_{1}\right)$ followed by culture on cells, was examined and compared to that of the original isolate of the ancestor virus. The mean cumulative mortality of rainbow trout was quantified through $35 \mathrm{~d}$ post challenge (Fig. 7). Rainbow trout infected with LR80 ancestor stock had a cumulative mortality of $42 \%( \pm 1 \% \mathrm{SE})$ (Fig. 7), the majority of which occurred between 5 and $14 \mathrm{~d}$ post virus exposure. The 3 passaged $\mathrm{P}_{1}$ viruses caused cumulative mortalities ranging between $42 \pm 4$ and $51 \pm 12 \%$ (Fig. 7), with similar kinetics as the LR80 ancestor. The negative control had $2 \%$ mortality. Survival analysis revealed that the inclusion of tank as a random effect did not improve model fit $\left(\mathrm{AIC}_{\mathrm{coxph}}\right.$ without random effect $=1139.4 \mathrm{vs}$. $\mathrm{AIC}_{\text {coxme }}$ with random effect $=1137.4, \Delta \mathrm{AIC}=1.91$ ). Thus, tank as a random effect was dropped from the analysis. Cox proportional hazards analysis revealed that infection by all isolates significantly increased 


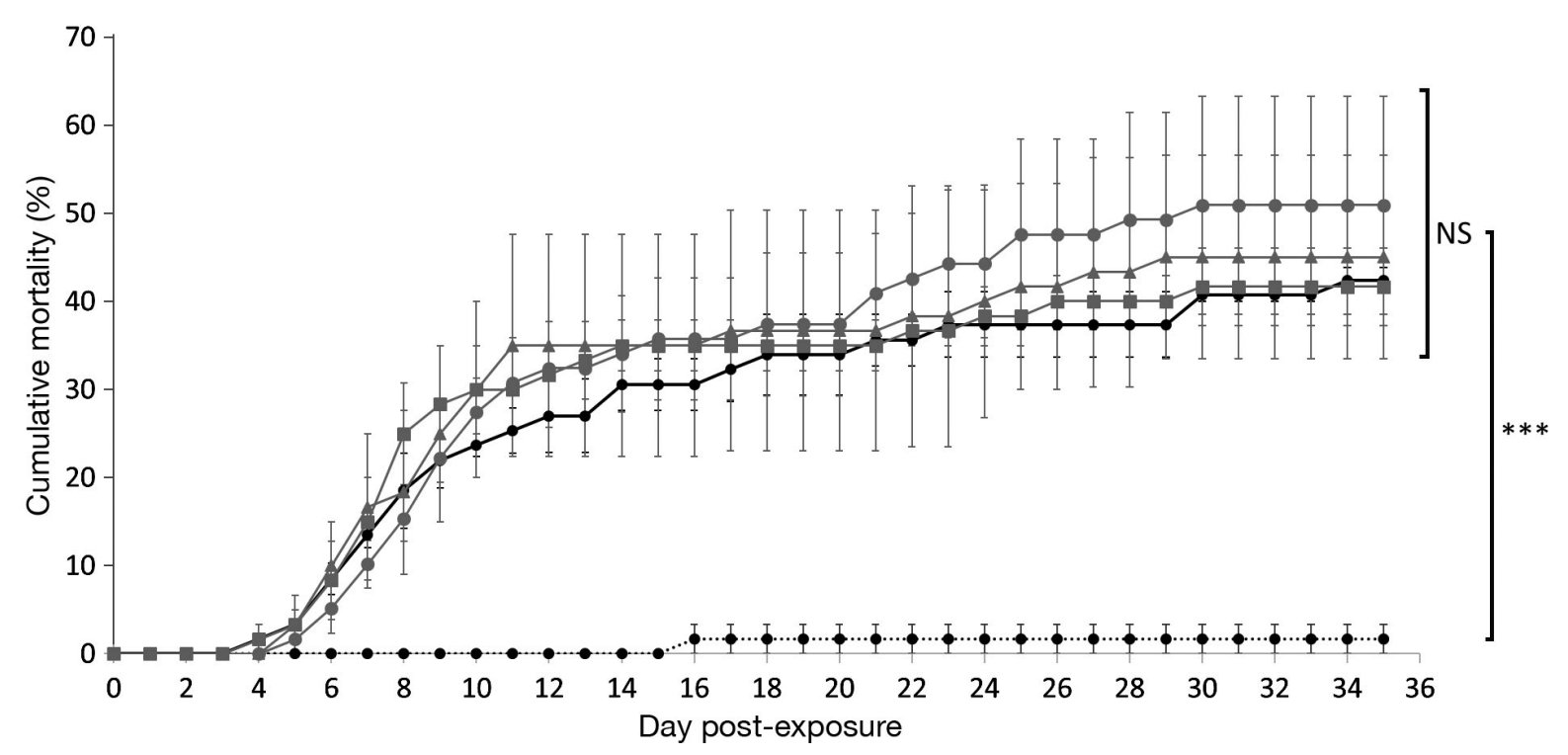

Fig. 7. Mean $( \pm \mathrm{SE})$ cumulative mortality of rainbow trout exposed to virus isolates after 1 round of transmission through rainbow trout (P1cell_1: ——; P1cell_2: ——; and P1cell_3: - - ). The LR80 virus isolate ancestor stock ( $\bullet-)$ and negative control ( $\cdots .$.$) are also included. Lines correspond to mean ( \pm \mathrm{SE})$ of triplicate tanks of 20 fish treatment ${ }^{-1}$. Vertical brackets show non-significant effect (NS) and significant effect $(* * * \mathrm{p}<0.0001)$. P: passage

fish mortality relative to the negative control (proportional hazards model comparing all isolates to negative control; $\mathrm{df}=4, \chi^{2}=52.89, \mathrm{p}<0.0001$; Fig. 7). However, mortality in all passaged virus treatments was not significantly different from the LR80 ancestor stock (proportional hazards model comparing all isolates to each other; $\mathrm{df}=3, \chi^{2}=0.77, \mathrm{p}=0.86$; Fig. 7).

\section{DISCUSSION}

We successfully developed a method to investigate fish-to-fish transmission of IHNV in rainbow trout and maintain transmission for up to 3 rounds of serial passage with an in vivo cohabitation design. Using our method, we were able to evaluate viral transmission rate and shedding kinetics throughout serial passage. We found that transmission success was $100 \%$ at the first passage and steadily decreased with each passage step to a minimum value of $62.5 \%$ at passage 3 . The mechanism driving this decrease in transmission success between serial passages is unknown, but it is likely a compounding effect of reductions in viral dosages. Infection probability of fish by IHNV is dose dependent, meaning fewer fish become infected as dose decreases (Ogut \& Reno 2004a, Wargo \& Kurath 2012, McKenney et al. 2016, Langwig et al. 2017). We intentionally chose the window of peak shedding to maximize probability of transmission in this study. However, it is also possible that shedding quantity is dose dependent, such that fish exposed to less virus shed a lower quantity of virus (Urquhart et al. 2008, Hershberger et al. 2010, 2011). In general, we observed that peak shedding was reduced at each serial passage step, likely resulting in fewer fish becoming infected and fish shedding a lower amount of virus at the subsequent passage steps, in a compounding fashion. Whether transmission continues to decline or plateau with additional passages warrants further exploration.

We also observed that infections became more asynchronous with increasing serial passage, i.e. the day and amount of peak shedding was more dispersed in $\mathrm{P}_{2}$ and $\mathrm{P}_{3}$ fish than in $\mathrm{P}_{0}$ fish. This may have also resulted in the window of peak transmission becoming more dispersed. To address this, we used pools of 3 fish at each passage rather than a single fish to provide a more complete representation of the between-fish variation in amount and timing of peak viral shedding. The mechanisms driving the observed shedding asynchrony are again unknown but likely to be a result of decreased and more variable viral exposure dosage with increasing passages, as follows. The $\mathrm{P}_{0}$ fish were exposed to a very high and uniform dosage of virus $\left(1 \times 10^{6} \mathrm{PFU} \mathrm{ml} \mathrm{m}^{-1}\right)$ because they were infected directly from a virus stock. In contrast, in subsequent passages, fish were exposed to virus shed by fish from the previous passage step. Because there are high levels of individual host variation in the duration and quantity of shedding (Wargo et al. 2017), the $\mathrm{P}_{1}-\mathrm{P}_{3}$ fish were likely exposed to more variable and generally lower doses $\left(10^{4}-10^{6}\right.$ RNA copies $\mathrm{ml}^{-1}$, roughly equal to $10^{2}-10^{3} \mathrm{PFU} \mathrm{ml}^{-1}$; Purcell et al. 2006) 
compared to the $\mathrm{P}_{0}$ fish. Empirical and theoretical studies in other systems have suggested that viral infection kinetics and synchrony can be dose dependent (Cummings et al. 2012, Littwitz-Salomon et al. 2017). Viruses may take longer to initiate infection and reach peak values at lower dosages compared to higher dosages (Chu \& Volety 1997, Cummings et al. 2012, Abdoli et al. 2013, Jarungsriapisit et al. 2016). This is further supported by our finding that peak shedding shifted from $48 \mathrm{~h}$ post immersion in fish challenged with virus grown in cell culture $\left(\mathrm{P}_{0}\right)$ to $72 \mathrm{~h}$ in fish exposed to virus shed from other fish $\left(\mathrm{P}_{1}-\mathrm{P}_{3}\right)$. In addition, host clearance may be faster at lower virus exposure doses (Jarungsriapisit et al. 2016).

Our results indicated that transmission success was notably lower when fish were placed alone in cohabitation with a single fish than when 3 donor fish were in cohabitation with 3 recipient fish. Although viral concentration in the water was sometimes greater in tanks with 3 fish (Expts 3 and 4) than tanks with 1 donor fish (Expts 1 and 2), there were just as many cases where viral concentration was equally as high when only 1 fish was present (Expts 5 and 6). However, higher densities always resulted in greater transmission, suggesting transmission success is driven by density effects in addition to viral exposure dose. Density effects on IHNV transmission have been observed by others (Ogut \& Reno 2004b). A variety of mechanisms could drive these density effects. Fish density produces a wide range of stressors in various fish species such as deterioration in water quality, overcrowding, or adverse social interactions (Pickering \& Pottinger 1987, Ellis et al. 2002). Some studies reported that a high fish density changes the susceptibility to diseases by down-regulating the immune system in rainbow trout (Cnaani 2006, Yarahmadi et al. 2016). Thus, physiological stress from high densities might be an important contributing factor in fish disease and mortality (Davis et al. 2002, Mateus et al. 2017). Such density effects could result in greater transmission rates in high-density host settings such as aquaculture (Olson \& Thomas 1994, Noble \& Summerfelt 1996, Lafferty et al. 2015) and have important evolutionary consequences (Kennedy et al. 2016). From an epidemiological perspective, models used to infer the dynamics of directly transmitted waterborne pathogens, such as IHNV, typically assume an absence of density effects (Anderson \& May 1992). Given our results, and those of others using this system, this assumption needs further evaluation to produce more accurate epidemiological inference (Dwyer et al. 1997, Fenton et al. 2002).

Another potential factor that could influence transmission probability is the duration of fish cohabitation.
In this study, we chose the longest cohabitation duration possible to allow transmission but prevent recipient fish from reinfecting donor fish. This and previous studies indicated that IHNV shedding begins between 25 and $48 \mathrm{~h}$ after the initiation of fish exposure to virus (Ogut \& Reno 2004a, Wargo et al. 2017). Therefore, by cohabitating fish for only $24 \mathrm{~h}$, recipient fish were not provided with enough time to begin shedding virus to reinfect recipient fish. This allows for powerful evolutionary studies because virus isolates can be phenotyped and genotyped at each passage step.

There was no change in genetics or virulence among the ancestral viral stock and the passaged isolates as measured by mortality or G gene sequence. Our goal was not to determine if serial passage results in small evolutionary changes in IHNV. Rather, our method was intended to quantify if initial movement of virus from cell culture to fish results in rapid changes in virulence. In SPEs under controlled laboratory conditions, the number of passages required to drive evolution of pathogens is highly variable (e.g. Brugh \& Perdue 1991, Ebert 1998, Mackinnon \& Read 2004, Chapuis et al. 2011, Barclay et al. 2012, Guidot et al. 2014, Valero-Jiménez et al. 2017). It is therefore possible that more than the 1 passage would be required to drive IHNV evolution. Likewise, although the cumulative mortality observed was similar to that of previous studies with this ancestral viral stock (Breyta et al. 2016), it is one of many phenotypic traits of the virus that could undergo evolution (Wargo \& Kurath 2012), and we cannot rule out the possibility of evolution in other traits. It should also be noted that the Sanger sequencing of the G gene used can only characterize the consensus sequence of the virus and will not reveal minority sequence variants (e.g. Wright et al. 2011, Iyer et al. 2015). The absence of changes in the $\mathrm{G}$ gene also does not eliminate the possibility of changes in other parts of the viral genome. Our results are consistent with previous studies that passage of the virus through a few generations of cell culture does not typically result in virus evolution (Gonzalez et al. 1991, Chen et al. 2003, Bellec et al. 2014). Additional studies examining whether or not multiple rounds of serial passage through fish results in evolution may be enlightening.

In conclusion, we developed a powerful tool to evaluate transmission efficiency using a cohabitation method of exposure that mimics the natural mode of IHNV transmission in rainbow trout. Although previous groups have investigated IHNV transmission during cohabitation, our method differed in several important ways. Perhaps the most notable difference is that previous studies have used a design in which 
large groups of fish are cohabitated for long periods of time (Amend 1975, Mulcahy et al. 1983, Traxler et al. 1993, Ogut \& Reno 2004b, Balmer et al. 2017). Given the acute nature of IHNV transmission, numerous rounds of transmission back and forth between donor and recipient fish likely occurred in these previous studies, making it impossible to determine the original source of transmission. In our study, small groups of fish were housed together for a short period of time, such that only 1 round of transmission was possible from donor to recipient fish. Furthermore, mortality has typically been used as the metric to verify transmission success, whereas we quantified the load of shed virus. Previous studies have indicated that many trout which become infected and shed virus do not die; thus, mortality likely underestimates transmission (Wargo et al. 2017). Our study design thus allows for detailed investigations of IHNV evolution, epidemiology, and disease dynamics under various environmental conditions, such as temperature, which may influence these dynamics. For example, this method could be used for calculation of important epidemiological parameters such as transmission rate $(\beta)$ and the basic reproduction number $\left(R_{0}\right)$ (van den Driessche \& Watmough 2002). To date, efforts to model IHNV dynamics have largely been reliant on viral shedding, field, and disease prevalence data to quantify transmission rates because of a lack of experimental data on fish-tofish transmission (Foreman et al. 2015, Ferguson et al. 2018). A better understanding of transmission will likely allow disease managers, particularly of IHNV in rainbow trout, to better predict the risk, timing, duration, and magnitude of epidemics.

Acknowledgements. The authors thank P. Dye, D. Jones, B. Rutan, and A. Taylor for technical assistance and fish care; and Clear Spring Foods for supplying fish. We also thank Prof. Jeffrey D. Shields for critical reading of the manuscript; and also thank 2 anonymous reviewers for helpful comments. This work is supported by Agriculture and Food Research Initiative grant 2015-67015-23112 from the US Department of Agriculture National Institute of Food and Agriculture.

\section{LITERATURE CITED}

Abdoli A, Soleimanjahi H, Kheiri MT, Jamali A, Jamaati A (2013) Determining influenza virus shedding at different time points in Madin-Darby canine kidney cell line. Cell J 15:130-135

Amend DF (1975) Detection and transmission of infectious hematopoietic necrosis virus in rainbow trout. J Wildl Dis 11:471-478

Anderson RM, May RM (1992) Infectious diseases of humans: dynamics and control. Oxford University Press, Oxford
Balmer BF, Powers RL, Zhang TH, Lee J and others (2017) Inhibition of an aquatic rhabdovirus demonstrates promise of a broad-spectrum antiviral for use in aquaculture. J Virol 91:e02181-e16

* Barclay VC, Sim D, Chan BH, Nell LA, Rabaa MA, Bell AS (2012) The evolutionary consequences of blood-stage vaccination on the rodent malaria Plasmodium chabaudi. PLOS Biol 10:e1001368

* Batts WN, Winton JR (1989) Enhanced detection of infectious hematopoietic necrosis virus and other fish viruses by pretreatment of cell monolayers with polyethylene glycol. J Aquat Anim Health 1:284-290

Bellec L, Cabon J, Bergmann S, de Boisséson C and others (2014) Evolutionary dynamics and genetic diversity from three genes of Anguillid rhabdovirus. J Gen Virol 95: 2390-2401

Bootland LM, Leong JC (2011) Infectious haematopoietic necrosis virus. In: Woo PTK, Bruno DW (eds) Fish diseases and disorders, Vol 3. Viral, bacterial and fungal infections. CABI Publishing, Wallingford, p 66-109

Breyta R, Jones A, Kurath G (2014) Differential susceptibility in steelhead trout populations to an emergent MD strain of infectious hematopoietic necrosis virus. Dis Aquat Org 112:17-28

* Breyta R, McKenney D, Tesfaye T, Ono K, Kurath G (2016) Increasing virulence, but not infectivity, associated with serially emergent virus strains of a fish rhabdovirus. Virus Evol 2:vev018

Breyta R, Brito I, Ferguson P, Kurath G and others (2017) Transmission routes maintaining a viral pathogen of steelhead trout within a complex multi-host assemblage. Ecol Evol 7:8187-8200

Brugh M, Perdue ML (1991) Emergence of highly pathogenic virus during selective chicken passage of the prototype mildly pathogenic chicken/Pennsylvania/83 (H5N2) influenza virus. Avian Dis 35:824-833

Chapuis É, Pagès S, Emelianoff V, Givaudan A, Ferdy JB (2011) Virulence and pathogen multiplication: a serial passage experiment in the hypervirulent bacterial insect-pathogen Xenorhabdus nematophila. PLOS ONE 6:e15872

* Chen WJ, Wu HR, Chiou SS (2003) E/NS1 modifications of dengue 2 virus after serial passages in mammalian and/or mosquito cells. Intervirology 46:289-295

* Chu FLE, Volety AK (1997) Disease processes of the parasite Perkinsus marinus in eastern oyster Crassostrea virginica: minimum dose for infection initiation, and interaction of temperature, salinity and infective cell dose. Dis Aquat Org 28:61-68

Cnaani A (2006) Genetic perspective on stress response and disease resistance in aquaculture. Isr $\mathrm{J}$ Aquacult 58: 375-383

* Cummings KW, Levy DN, Wodarz D (2012) Increased burst size in multiply infected cells can alter basic virus dynamics. Biol Direct 7:16

* Davis KB, Griffin BR, Gray WL (2002) Effect of handling stress on susceptibility of channel catfish Ictalurus punctatus to Ichthyophthirius multifiliis and channel catfish virus infection. Aquaculture 214:55-66

* Dixon P, Paley R, Alegria-Moran R, Oidtmann B (2016) Epidemiological characteristics of infectious hematopoietic necrosis virus (IHNV): a review. Vet Res 47:63

* Dwyer G, Elkinton JS, Buonaccorsi JP (1997) Host heterogeneity in susceptibility and disease dynamics: tests of a mathematical model. Am Nat 150:685-707 
Ebert D (1998) Experimental evolution of parasites. Science 282:1432-1436

Ellis T, North B, Scott AP, Bromage NR, Porter M, Gadd D (2002) The relationships between stocking density and welfare in farmed rainbow trout. J Fish Biol 61:493-531

Fenton A, Fairbairn JP, Norman R, Hudson PJ (2002) Parasite transmission: reconciling theory and reality. J Anim Ecol 71:893-905

Ferguson PFB, Breyta R, Brito I, Kurath G, LaDeau SL (2018) An epidemiological model of virus transmission in salmonid fishes of the Columbia River Basin. Ecol Model 377:1-15

Fijan N, Sulimanovi D, Bearzotti M, Muzini D and others (1983) Some properties of the Epithelioma papulosum cyprini (EPC) cell line from carp Cyprinus carpio. Ann Inst Pasteur Virol 134:207-220

Foreman MG, Guo M, Garver KA, Stucchi D and others (2015) Modelling infectious hematopoietic necrosis virus dispersion from marine salmon farms in the Discovery Islands, British Columbia, Canada. PLOS ONE 10: e0130951

* Garver KA, Batts WN, Kurath G (2006) Virulence comparisons of infectious hematopoietic necrosis virus $U$ and $\mathrm{M}$ genogroups in sockeye salmon and rainbow trout. J Aquat Anim Health 18:232-243

Garver KA, Mahony AAM, Stucchi D, Richard J, Van Woensel C, Foreman M (2013) Estimation of parameters influencing waterborne transmission of infectious hematopoietic necrosis virus (IHNV) in Atlantic salmon (Salmo salar). PLOS ONE 8:e82296

Gonzalez MJ, Saiz JC, Laor O, Moore DM (1991) Antigenic stability of foot-and-mouth disease virus variants on serial passage in cell culture. J Virol 65:3949-3953

Guidot A, Jiang W, Ferdy JB, Thébaud C, Barberis P, Gouzy J, Genin S (2014) Multihost experimental evolution of the pathogen Ralstonia solanacearum unveils genes involved in adaptation to plants. Mol Biol Evol 31: 2913-2928

Kershberger P, Gregg J, Grady C, Collins R, Winton J (2010) Kinetics of viral shedding provide insights into the epidemiology of viral hemorrhagic septicemia in Pacific herring. Mar Ecol Prog Ser 400:187-193

Hershberger PK, Gregg JL, Grady CA, Hart LM, Roon SR, Winton JR (2011) Factors controlling the early stages of viral haemorrhagic septicaemia epizootics: low exposure levels, virus amplification and fish-to-fish transmission. J Fish Dis 34:893-899

* Iyer S, Casey E, Bouzek H, Kim M and others (2015) Comparison of major and minor viral SNPs identified through single template sequencing and pyrosequencing in acute HIV-1 infection. PLOS ONE 10:e0135903

* Jarungsriapisit J, Moore LJ, Mæhle S, Skår C and others (2016) Relationship between viral dose and outcome of infection in Atlantic salmon, Salmo salar L., post-smolts bath-challenged with salmonid alphavirus subtype 3 . Vet Res 47:102

Kell AM, Wargo AR, Kurath G (2013) The role of virulence in in vivo superinfection fitness of the vertebrate RNA virus infectious hematopoietic necrosis virus. J Virol 87: 8145-8157

Kell AM, Wargo AR, Kurath G (2014) Viral fitness does not correlate with three genotype displacement events involving infectious hematopoietic necrosis virus. Virology 464-465:146-155

Kennedy DA, Kurath G, Brito IL, Purcell MK, Read AF, Win- ton JR, Wargo AR (2016) Potential drivers of virulence evolution in aquaculture. Evol Appl 9:344-354

Kim K, Dobson AP, Gulland FMD, Harvell CD (2005) Diseases and the conservation of marine biodiversity. In: Norse EA, Crowder LB (eds) Marine conservation biology: the science of maintaining the sea's biodiversity. Island Press, Washington, DC, p 149-166

Kurath G, Garver KA, Troyer RM, Emmenegger EJ, EinerJensen K, Anderson ED (2003) Phylogeography of infectious hematopoietic necrosis virus in North America. J Gen Virol 84:803-814

K Lafferty KD, Harvell CD, Conrad JM, Friedman CS and others (2015) Infectious diseases affect marine fisheries and aquaculture economics. Annu Rev Mar Sci 7:471-496

* Langwig KE, Wargo AR, Jones DR, Viss JR and others (2017) Vaccine effects on heterogeneity in susceptibility and implications for population health management. MBio 8: e00796-17

LaPatra SE, Rohovec JS, Fryer JL (1989) Detection of infectious hematopoietic necrosis virus in fish mucus. Fish Pathol 24:197-202

Kittwitz-Salomon E, Schimmer S, Dittmer U (2017) Dose of retroviral infection determines induction of antiviral NK cell responses. J Virol 91:e01122-17

Mackinnon MJ, Read AF (2004) Immunity promotes virulence evolution in a malaria model. PLOS Biol 2:e230

Mateus AP, Power DM, Canário AVM (2017) Stress and disease in fish. In: Jeney G (ed) Fish diseases: prevention and control strategies. Academic Press, London, p $187-220$

McKenney DG, Kurath G, Wargo AR (2016) Characterization of infectious dose and lethal dose of two strains of infectious hematopoietic necrosis virus (IHNV). Virus Res 214:80-89

*Mulcahy D, Pascho RJ, Jenes CK (1983) Detection of infectious haematopoietic necrosis virus in river water and demonstration of waterborne transmission. J Fish Dis 6: 321-330

Nelson KE, Williams CM (2013) Infectious disease epidemiology: theory and practice. Jones \& Bartlett Learning, Burlington, MA

Nichol ST, Rowe JE, Winton JR (1995) Molecular epizootiology and evolution of the glycoprotein and non-virion protein genes of infectious hematopoietic necrosis virus, a fish rhabdovirus. Virus Res 38:159-173

* Nishimura T, Ishida Y, Yamamoto S, Fukuda H, Okamoto N, Sano $T$ (1988) Infectious hematopoietic necrosis: virus titer in the fish bodies, rearing water and feces of artificially infected rainbow trout fry. Fish Pathol 23:13-17

Noble AC, Summerfelt ST (1996) Diseases encountered in rainbow trout cultured in recirculating systems. Annu Rev Fish Dis 6:65-92

\% Ogut H, Reno PW (2004a) Early kinetics of infectious hematopoietic necrosis virus (IHNV) infection in rainbow trout. J Aquat Anim Health 16:152-160

Ogut H, Reno PW (2004b) Effects of fish density on spread of infectious hematopoietic necrosis virus (IHNV) in rainbow trout, Oncorhynchus mykiss. Isr J Aquacult 56: 218-225

OIE (World Organisation for Animal Health) (2017) Chap 2.3.4, Infectious haematopoietic necrosis virus. In: Manual of diagnostic tests for aquatic animals. www.oie.int/ international-standard-setting/aquatic-manual/accessonline/ (accessed on 27 April 2018)

Olson C, Thomas J (1994) An outbreak of infectious hemato- 
poietic necrosis in the Baker River system affecting two year classes of sockeye. Fish Health Sect, Am Fish Soc Newsl 22:1-3

Peñaranda MMD, Wargo AR, Kurath G (2011) In vivo fitness correlates with host-specific virulence of infectious hematopoietic necrosis virus (IHNV) in sockeye salmon and rainbow trout. Virology 417:312-319

Pickering AD, Pottinger TG (1987) Poor water quality suppresses the cortisol response of salmonid fish to handling and confinement. J Fish Biol 30:363-374

Purcell MK, Hart SA, Kurath G, Winton JR (2006) Strandspecific, real-time RT-PCR assays for quantification of genomic and positive-sense RNAs of the fish rhabdovirus, infectious hematopoietic necrosis virus. J Virol Methods 132:18-24

Purcell MK, Thompson RL, Garver KA, Hawley LM and others (2013) Universal reverse-transcriptase real-time PCR for infectious hematopoietic necrosis virus (IHNV). Dis Aquat Org 106:103-115

R Core Team (2013) R: a language and environment for statistical computing. Foundation for Statistical Computing, Vienna. www.R-project.org

Saksida SM (2006) Infectious haematopoietic necrosis epidemic (2001 to 2003) in farmed Atlantic salmon Salmo salar in British Columbia. Dis Aquat Org 72:213-223

Schütze H, Enzmann PJ, Kuchling R, Mundt E, Niemann H, Mettenleiter TC (1995) Complete genomic sequence of the fish rhabdovirus infectious haematopoietic necrosis virus. J Gen Virol 76:2519-2527

Therneau $\mathrm{T}$ (2015) coxme: mixed effects Cox models. $\mathrm{R}$ package version 2.2-10. https://cran.r-project.org/ package $=$ coxme

Therneau TM, Grambsch PM (2000) Modeling survival data: extending the Cox model. Springer, New York, NY

* Traxler GS, Roome JR, Kent ML (1993) Transmission of infectious hematopoietic necrosis virus in seawater. Dis Aquat Org 16:111-114

Troyer RM, Kurath G (2003) Molecular epidemiology of infectious hematopoietic necrosis virus reveals complex virus traffic and evolution within southern Idaho aquaculture. Dis Aquat Org 55:175-185

Uurquhart K, Murray AG, Gregory A, O'Dea M, Munro LA, Smail DA (2008) Estimation of infectious dose and viral shedding rates for infectious pancreatic necrosis virus in
Atlantic salmon, Salmo salar L., post-smolts. J Fish Dis 31:879-887

Valero-Jiménez CA, van Kan JAL, Koenraadt CJM, Zwaan BJ, Schoustra SE (2017) Experimental evolution to increase the efficacy of the entomopathogenic fungus Beauveria bassiana against malaria mosquitoes: effects on mycelial growth and virulence. Evol Appl 10:433-443

van den Driessche P, Watmough J (2002) Reproduction numbers and sub-threshold endemic equilibria for compartmental models of disease transmission. Math Biosci 180:29-48

*Wargo AR, Kurath G (2011) In vivo fitness associated with high virulence in a vertebrate virus is a complex trait regulated by host entry, replication, and shedding. J Virol 85:3959-3967

*Wargo AR, Kurath G (2012) Viral fitness: definitions, measurement, and current insights. Curr Opin Virol 2: 538-545

Wargo AR, Garver KA, Kurath G (2010) Virulence correlates with fitness in vivo for two $M$ group genotypes of infectious hematopoietic necrosis virus (IHNV). Virology 404: $51-58$

*Wargo AR, Kell AM, Scott RJ, Thorgaard GH, Kurath G (2012) Analysis of host genetic diversity and viral entry as sources of between-host variation in viral load. Virus Res 165:71-80

*Wargo AR, Scott RJ, Kerr B, Kurath G (2017) Replication and shedding kinetics of infectious hematopoietic necrosis virus in juvenile rainbow trout. Virus Res 227:200-211

* Wright CF, Morelli MJ, Thébaud G, Knowles NJ and others (2011) Beyond the consensus: dissecting within-host viral population diversity of foot-and-mouth disease virus by using next-generation genome sequencing. J Virol 85: 2266-2275

* Yarahmadi P, Miandare HK, Fayaz S, Caipang CMA (2016) Increased stocking density causes changes in expression of selected stress- and immune-related genes, humoral innate immune parameters and stress responses of rainbow trout (Oncorhynchus mykiss). Fish Shellfish Immunol 48:43-53

Yourth CP, Schmid-Hempel P (2006) Serial passage of the parasite Crithidia bombi within a colony of its host, Bombus terrestris, reduces success in unrelated hosts. Proc R Soc Lond B Biol Sci 273:655-659

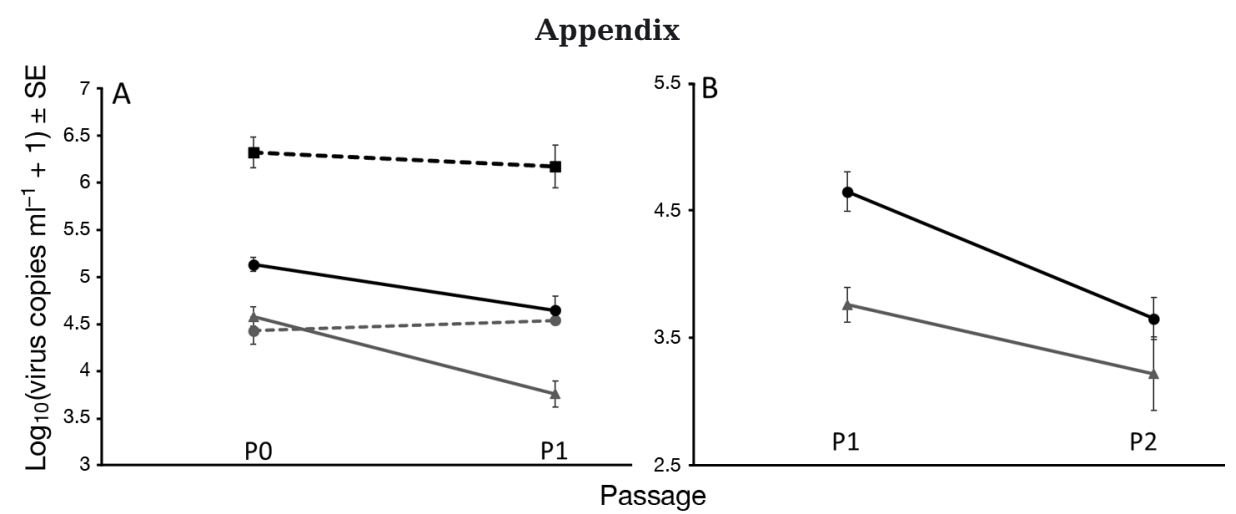

Fig. A1. Mean $( \pm \mathrm{SE})$ cumulative virus shed after $24 \mathrm{~h}$ cohabitation between passages $(\mathrm{P})$ at each experiment (Expt 3: - - $;$ Expt 4: ---; Expt 5: - - ; and Expt 6: - ). Comparison in viral shedding (A) between $\mathrm{P}_{0}$ and $\mathrm{P}_{1}$ and $(\mathrm{B})$ between $\mathrm{P}_{1}$ and $\mathrm{P}_{2}$. Shedding data of $\mathrm{P}_{0}$ fish were at Day 2 post immersion and at Day 3 for $\mathrm{P}_{1}$ to $\mathrm{P}_{3}$ 